UDC 021.2-048.78:378.4(477.83-25)

FIHEL O. M.

Scientific Library, Ivan Franko National University of Lviv (Lviv, Ukraine), e-mail: olena.fihel@lnu.edu.ua, ORCID 0000-0002-6809-853X

\title{
SCIENTIFIC AND EDUCATIONAL ACTIVITY OF LIBRARIES AS A CRITERION OF LIBRARY REFORM
}

Objective. The article examines the legislation of Ukraine in the framework of library reform. It is noted that in the presence of all changes and additions, the wording of the Law of Ukraine "On Libraries and Library Affairs" of 2021 regulates the activities of mostly public libraries. The peculiarities of the activity of libraries of higher educational institutions (HEI) are not reflected in the law. Methods. The methodological basis of the study were: general methods of thinking; general scientific and interdisciplinary methods. We can also distinguish: analysis and synthesis, abstraction, formalization and dialectical, as a general scientific method of cognition. Results. An example of a legal conflict regarding the legitimacy to use the status of a research and educational worker by the director of a University library is analyzed in detail. The study proves that libraries of higher education institutions are not obliged to conduct research and educational activities. However, in the absence of scientific lectures, workshops, and research, the library is reduced to the level of a subdivision of the HEI, whose activities are aimed only at providing information on scientific and educational activities of teachers and students. Conclusions. On the example of the Scientific Library of Ivan Franko National University of Lviv, known in Ukraine and abroad for its scientific lectures, art projects, research and explorations, the relevance and importance of conducting scientific and educational activities by Scientific Libraries of the HEI is shown.

Keywords: library legislation; scientific and educational activity; scientific and educational worker, Scientific Library of Ivan Franko National University of Lviv

\section{Introduction}

At present, the current legislation of Ukraine, in particular the standards stipulating the staffing plan formation of libraries of the higher education institutions, meet the requirements of the 70s of the last century. In 2012, the latest amendments were made to the Order of the Ministry of Education and Science, Youth and Sports of Ukraine No. 1058, dated 27.09.2012 "On Approval of the Staffing Standards and Structure for Libraries of Higher Educational Institutions of III-IV Accreditation Levels". According to this Order, a modern powerful university library conducting scientific activities cannot afford to properly organize certain types of work and offer decent wages either to librarians who are paid from the 8th category of the Unified Tariff System, or to IT sector representatives who are paid at the 6th level of the above mentioned category. As for scientific restoration, libraries can count on only one specialist with a minimum salary according to the requirements of the order.

In April 2020, at a meeting of the Committee on Humanitarian and Information Policy, people's deputies considered a bill amending the Law "On Libraries and Library Affairs" No. 5002 (Pro Vnesennia Zmin, 2021). In addition, the project was submitted for public discussion, which took place on May 20, 2020 in the format of an online conference. The event was attended by representatives of local governments, libraries at various levels, including the Scientific Library of Ivan Franko National University of Lviv, the public sector, publishers and users of library services. As a result of the public discussion, the Ministry received more than 90 letters with suggestions and comments, which were processed by the working group.

Amendments to the Law of Ukraine "On Libraries and Library Affairs" were conditioned by the need to provide a legislative basis for the further development of the library business in accordance with modern requirements. 
The current Law of Ukraine "On Libraries and Library Affairs" was adopted in 1995, and its new version - in 2000. Some of the provisions of the Law are outdated, purely declarative and impossible to be implemented and enforced.

The wording of the Law of 2021 (Explanatory Note to the Draft Law of Ukraine "On Amendments to the Law of Ukraine "On Libraries and Library Affairs" (2021)) expanded and updated the conceptual and terminological apparatus, added a number of new terms and clarified the existing ones (for example, there are added the following terms such as "electronic database", "electronic document", "book memo", etc.); proposed the modern classification of libraries by forms of ownership and value, by public purpose; defined and assigned the library functions: specified the tasks and functions of national and state libraries in accordance with international standards, as well as the norms for special libraries; brought the norms on creation, reorganization and liquidation of libraries in line with the legislation on legal entities; introduced the concept of a library supervisory board as an advisory collegian body, whose main task is to promote the library development, etc.

Unfortunately, it can be stated that in the presence of all changes and additions, the Law of Ukraine "On Libraries and Library Affairs" regulates the activities of mostly public libraries. Peculiarities of the activity of special libraries, in particular libraries of higher education institutions (HEIs), are not reflected in the law.

The activity of libraries of higher education institutions is aimed at fulfilling the main task - promoting the proper information support of educational, upbringing and research processes of higher education.

\section{Methods}

The methodological basis of the study were the following groups of methods: general methods of thinking; general and interdisciplinary scientific methods. Along with other general methods of thinking used in the study, we can distinguish: analysis and synthesis (facilitating the separation, analysis and synthesis of legislation governing the basic rights and responsibilities of research and teaching staff), abstraction (emphasis on the forms implementation of legal bases of scientific and educational activity in the library sphere) and formalization (assistance in formalization of recommendations developed in the work on preservation of the status of the Scientific Library of HEI in general and the position of director in particular, in the form of specific proposals for amendments to certain provisions of the Law of Ukraine "On Higher Education" (2017) and other legislative acts).

The dialectical method was used among the general scientific methods of cognition, which helped to distinguish the relationship between the activities of the university library and its status.

\section{Results and Discussion}

For the last few years, the Scientific Library of Ivan Franko National University of Lviv, as the Zonal Methodological Center of the HEI Libraries of the Western Region of Ukraine, has been monitoring the priority areas of university libraries. Libraries of higher education institutions created information bases for the organization of educational and research processes, provided fast and convenient access to world scientific and educational resources, as well as created their own electronic resources. Organically combining the use of documentary and electronic information resources, they were full-fledged participants in the academic and research processes at their universities, in particular: modernized library and information services; introduced effective forms of user service, including remote one; supported the principles of academic integrity; cooperated 
with structural subdivisions of universities, providing resources and services to support educational and research programs, as well as cooperated with scientific institutions and libraries of Ukraine and the world.

In recent years, the reporting documentation of university libraries, articles, conference reports say a lot about the introduction of innovative ideas and new technologies that modern users need. Who is essentially a modern user? What technologies are new to him/her? From the library reports, we can see that sometimes the purchase of several computers for the library is perceived as the introduction of new technologies in the activities of the institution.

Now, a modern user is mostly a young person who, from the first days of his life, has more than just an ordinary computer. This is a person who grew up with a smartphone. For him or her, computer technology is a normal part of life. That is why the priority of libraries should be to ensure that technical progress is not considered by libraries as some abstract and distant future.

Quarantine proved that the organization of a modern library system should be based not only on the automation of a particular library. The main goal should be to create a single allUkrainian information space and strengthen the integration into the global library information space. Besides, to provide the possibility of quality remote service - from user registration (with simultaneous authorization), consultation, to electronic order. To achieve this goal it is necessary to solve a number of tasks: firstly, improving library and bibliographic information and publication of texts in electronic form; secondly, providing Internet access to bibliographic information and full-text databases; thirdly, providing electronic means of searching and servicing requests for information resources of the library (Karashchuk, 2016).

2020 was remembered not only for the beginning of quarantine. According to the Law of Ukraine "On Higher Education" (2017), the planned accreditation of educational master programs were conducted in higher education institutions. Universities also went through annual financial inspections by the authorities. Some university libraries have lost their scientific status.

The Scientific Library of Ivan Franko National University of Lviv, due to the fact that it is the Zonal Methodological Center of HEI Libraries of the Western Region of Ukraine, acted as a consultant, trying to provide all possible assistance to colleagues from other universities that awaited quite unpleasant "surprises" as a result of inspections. In particular, several university libraries received instructions from the Financial Inspectorate stating that the director of the library illegally used the a scientific and educational staff status. As expected, colleagues considered this conclusion of the Financial Inspectorate unfounded, in their defense referred to the Law of Ukraine on "Higher Education", Article 33, paragraph 3, which defines: "The main structural units of higher education institutions (except for colleges that do not provide bachelor's degree training) are faculties, departments, library". And Article 55 "Main positions of academic, research and educational staff of higher education institutions and the appointment procedure", where paragraph 5 states that the position of the library director belongs to the category of research and educational staff.

It would seem that the instructions of the financial inspection can be considered unfounded, which is confirmed by the Law of Ukraine "On Higher Education" (2017), directors of university libraries are and should remain scientific and educational staff. However, as the Financial Inspectorate rightly points out, a scientific and educational professional must have a range of responsibilities and powers that correspond to scientific and educational activities.

The activity of the HEI library, which is aimed only at providing information to teachers and students, cannot be attributed to scientific and educational activities. And the activity of the library of the higher education institution in general is aimed at providing information to teachers and students. 
According to the Model Regulations on the Library of a Higher Educational Institution of III-IV Accreditation Levels: "Library is a structural subdivision of a higher educational institution of III-IV accreditation levels, which provides literature and information to the educational and scientific process of a higher educational institution and operates on the basis of the Library Regulations approved by the head of the higher educational institution." (Ministry of Education and Science of Ukraine, 2004).

Since the library of a higher education institution is not an independent legal entity, but only its structural unit, therefore, according to lawyers, the library as a structural unit of the institution can be managed not even by the director, but by the head of the library.

Thus, as a result of research on the recognition of the position of the university library director as scientific and educational, we obtained the following result: it is not so much about the recognition of the director position as scientific and educational, but about the legitimacy of the term "director"!

The Handbook of Qualification Characteristics of Employees' Professions in the section "Libraries, Centralized Library Systems" does not indicate among the tasks and responsibilities of the library director the performance of his/her educational work in a higher education institution, which is integral and basic for scientific and educational staff (Ministry of Education and Science of Ukrain, 2000).

In addition, librarians receive all surcharges and benefits in accordance with the law on librarianship, not on higher education. The regulated mode of work of librarians also does not coincide with the mode of work of scientific and pedagogical workers. The duties of librarians do not include the performance of scientific and educational work in a particular discipline within the framework of the higher education institutions, which is mandatory for scientific and pedagogical workers.

The Law of Ukraine "On Higher Education (2017), Part 3, Article 55 states: "The full list of positions of scientific-educational and academic staff of higher education institutions is established by the Cabinet of Ministers of Ukraine".

List of positions of scientific-educational and academic staff is established by the Resolution of the Cabinet of Ministers of Ukraine (2000) No. 963 of 14.06.2000, which indicates the positions of scientific and educational staff. The above-mentioned List (Resolution of the Cabinet of Ministers of Ukraine "On Approval of the List of Positions of Scientific-Educational and Academic Staff", 2000) is used to address issues related to the implementation of Article 57 of the Law of Ukraine "On Education" to determine persons entitled to seniority pay, recuperation pay during annual vacation, and Article 6 of the Law of Ukraine "On Holidays" (2021) to determine the duration of the main annual leave.

The section IV of the Resolution of the Cabinet of Ministers of Ukraine "On Approval of the Procedure for Granting Annual Basic Vacation for up to 56 Calendar Days to Managers of Educational Institutions, Educational (Pedagogical) Units (Subdivisions) of Other Institutions, Pedagogical, Scientific and Educational Workers and Researchers” No. 346 of April 14, 1997, contains a list of positions of pedagogical, scientific and educational and academic workers. It does not include the position of a library director (Cabinet of Ministers of Ukraine, 1997).

The study showed that in practice there is a situation when according to one list the position is scientific and educational, and according to another it is not, that it leads to misunderstandings due to the ambiguity of its application.

Thus, there is a rather unpleasant situation, which arose on the one hand, due to the imperfection of the legislation, where there is both the Law and the Resolution, which eliminates this law. On the other hand, the Resolution could be disregarded if the library carried out scientific and educational activities. 
Our research allows us to conclude that libraries of higher education institutions are not obliged to conduct scientific and educational activities. No Order recognizes this type of activity as mandatory, but in the absence of scientific lectures, workshops, active educational work and scientific activities, the library is reduced to the level of a freelance unit, whose activities are aimed only at providing information on scientific and educational activities for teachers and students. Changing the status of the position of the university library director will lead to the removal of all other management positions in the department and revision of the staff list in the direction of reducing the number of departments and employees of the library.

\section{Conclusions}

During 2020-2021, we thoroughly monitored and analyzed the situation with the availability of scientific and educational rates in the HEI libraries. This was due to the peculiarities of the Scientific Library of Ivan Franko National University of Lviv, which is a platform for scientific and socio-educational activities that stimulate public interest in the University and its scientific and educational process. The scientific library is well known for its scientific lectures, art projects, career guidance activities and research activities. Scientific lectures of the Scientific Library are attended by students and scientists of the HEI of Ukraine and abroad. There are 3 scientific researches taking place simultaneously, one of which is funded by the state budget. Scientific activity is annually confirmed by the defense of scientific reports. F. P. Maksymenko Department for Manuscripts, Old Prints and Rarities of Scientific Library has the status of a national heritage. Therefore, the scientific activity of the employees of the unit is confirmed by the ministerial annual reports. As a methodical center of the Lviv zonal methodical association of libraries of higher education institutions, the Scientific Library of Ivan Franko National University of Lviv organizes and conducts scientific internships for employees of libraries of all forms and departments of Ukraine and abroad.

In 2021, a proposal to introduce additional scientific and scientific-pedagogical rates in the staff list of the Scientific Library of Lviv University was submitted to the Ministry of Education.

While some ministerial offices are considering the submission, others are preparing a document stating that Article 55 of the Law of Ukraine "On Higher Education" (2017) needs to be amended regarding the main positions of scientific and educational staff. The Ministry of Education and Science of Ukraine proposes to remove the positions of directors of HEI libraries from the list of main positions of scientific and educational staff. However, we know from a recent speech by the chairman of the Ukrainian Library Association, that this bill has not yet been registered for consideration by the Verkhovna Rada of Ukraine. If this happens, both people and hundreds of unique collections will be endangered. In particular, the Department for Manuscripts, Old Prints and Rarities of our library, which houses manuscripts of the early 13th century. From a library that conducts scientific activities, we can become custodians of funds, librarians who provide only information services. After all, by law, university library staff is support staff.

In the information society, education is constantly evolving, and to guarantee the prospect of acquiring new knowledge to all who seek it is only possible with the help of information resources and scientific activities of book collections. That is why the scientific and educational function of libraries acquires special importance.

Note that in every situation you should remain optimistic and make the most of any opportunities to achieve a positive result. Therefore, the situation with uncertainty about the scientific and educational activities in scientific libraries should be monitored, to unite the efforts of all HEI libraries, which carry out powerful scientific activity. After all, if the Ministry of Education receives substantiated proposals for legislative regulation of scientific and scientific- 
educational activities of academic libraries not from one or two institutions, but from all powerful university libraries, we have a chance to get an adequate and positive response from the authorities.

In turn, the Scientific Libraries of the HEI must continue to conduct scientific and scientific-educational activities, actively work on the implementation of promising projects, which will help university libraries to always be successful and needed by our users.

\section{REFERENCES}

Cabinet of Ministers of Ukraine. (1997). Pro zatverdzhennia Poriadku nadannia shchorichnoi osnovnoi vidpustky tryvalistiu do 56 kalendarnykh dniv kerivnym pratsivnykam zakladiv ta ustanov osvity, navchalnykh (pedahohichnykh) chastyn (pidrozdiliv) inshykh ustanov $i$ zakladiv, pedahohichnym, naukovo-pedahohichnym pratsivnykam ta naukovym pratsivnykam: Postanova № 346. Retrieved from https://zakon.rada.gov.ua/laws/show/346-97-\%D0\%BF\#Text (in Ukrainian)

Cabinet of Ministers of Ukraine. (2000). Pro zatverdzhennia pereliku posad pedahohichnykh ta naukovopedahohichnykh pratsivnykiv: Postanova № 963. Retrieved from https://zakon.rada.gov.ua/laws/show/963-2000-\%D0\%BF\#Text (in Ukrainian)

Karashchuk, O. (2016). The library in modern information space. Naukovi Pratsi Natsionalnoi Biblioteky Ukrainy Imeni V. I. Vernadskoho, 43, 596-610. Retrieved from http://nbuv.gov.ua/UJRN/npnbuimviv_2016_43_38 (in Ukrainian)

Ministry of Education and Science of Ukraine. (2000). Dovidnyk kvalifikatsiinykh kharakterystyk profesii pratsivnykiv. Vypusk 81 "Kultura ta mystetstvo": Nakaz № 168. Retrieved from https://zakon.rada.gov.ua/rada/show/v0168280-00\#Text (in Ukrainian)

Ministry of Education and Science of Ukraine. (2004). Prymirne polozhennia pro biblioteku vyshchoho navchalnoho zakladu III-IV rivniv akredytatsii: Nakaz № 641. Retrieved from http://www.library.univ.kiev.ua/ukr/for_lib/nakazmou.html (in Ukrainian)

Pro Vidpustky: Zakon Ukrainy 1996, № 504/96-VR stattia 6. (2021). Retrieved from https://zakon.rada.gov.ua/laws/show/504/96-\%D0\%B2\%D1\%80\#Text (in Ukrainian)

Pro Vnesennia Zmin do Zakonu Ukrainy "Pro Biblioteky i Bibliotechnu Spravu”: proiekt Zakonu Ukrainy 2021, № 5002. (2021). Retrieved from https://ips.ligazakon.net/document/view/ji04216i?an=3\&ed=2021_09_08 (in Ukrainian)

Pro Vyshchu Osvitu: Zakon Ukrainy 2014, № 1556-VII. (2017). Retrieved from https://zakon.rada.gov.ua/laws/show/1556-18\#Text (in Ukrainian)

FIHEL O. M.

Наукова бібліотека, Львівський національний університет імені Івана Франка (Львів, Україна), e-mail: olena.fihel@lnu.edu.ua, ORCID 0000-0002-6809-853X

\section{НАУКОВО-ОСВІТНЯ ДІЯЛЬНІСТЬ БІБЛІОТЕК ЯК КРИТЕРІЙ БІБЛІОТЕЧНОЇ РЕФОРМИ}

Мета. У статті досліджено законодавство України в рамках бібліотечної реформи. Відзначено, що при наявності усіх змін та доповнень, редакція Закону України "Про бібліотеки і бібліотечну справу" 2021 р. упорядковує діяльність здебільшого публічних бібліотек. Особливості діяльності бібліотек закладів вищої освіти у законі не відображені. Методика. Методологічну основу дослідження склали: загальні методи мислення; загальнонаукові методи та міждисциплінарні. Також можна виділити: аналіз та синтез, абстрагування, формалізації та діалектичний, як загальнонауковий метод пізнання. Результати. Докладно проаналізовано приклад правової колізії щодо правомірності використання директором бібліотеки ЗВО статусу науково-педагогічного працівника. Проведене дослідження доводить: бібліотеки закладів вищої освіти не зобов'язані проводити науково-педагогічну діяльність. Проте за відсутності наукових лекторіїв, 
практикумів, та наукових досліджень бібліотека зводиться до рівня підрозділу ЗВО, діяльність якого спрямована тільки на інформаційне забезпечення наукової і освітньої діяльності викладачів та студентів. Висновки. На прикладі Наукової бібліотеки ЛНУ імені Івана Франка, відомої в Україні та за межами держави своїми науковими лекторіями, мистецькими проєктами, науковими дослідженнями і розвідками, показано актуальність та важливість ведення науково-освітньої діяльності Науковими бібліотеками 3ВО.

Keywords: бібліотечне законодавство; науково-педагогічна діяльність; науково-педагогічний працівник, Наукова бібліотека ЛНУ імені Івана Франка

Received: 01.08.2021

Accepted: 30.11.2021 